\title{
Annually Laminated Speleothems: a Review
}

\author{
Andy Baker ${ }^{1}$, Claire L. Smith², Catherine Jex ${ }^{4}$, Ian J. Fairchild ${ }^{1}$, Dominique Genty ${ }^{3}$ \\ and Lisa Fuller ${ }^{1}$
}

\begin{abstract}
:
Baker A., Smith C.L., Jex C., Fairchild I.J., Genty D. and Fuller L. 2008. Annually Laminated Speleothems: a Review. International Journal of Speleology, 37 (3), 193-206. Bologna (Italy). ISSN 0392-6672.

This review of annually laminated speleothems firstly considers the four types of annual laminae found within speleothems: fluorescent laminae formed by annual variations in organic matter flux; visible or petrographic laminae, formed by annual variations in calcite texture or fabric; calcite-aragonite couplets; and finally trace element laminae. The methods available to confirm the annual nature, or otherwise, of lamina deposition are reviewed. We consider the use of annual laminae in chronology building, with particular relevance to palaeoclimate reconstructions. Finally, the use of annual lamina width as a palaeoclimate proxy is reviewed.
\end{abstract}

Keywords: speleothem, stalagmite, annual laminae, paleoclimate, geochronology

Received 4 July 2008; Revised 11 September 2008; Accepted 16 October 2008

\section{INTRODUCTION}

The idea that speleothems might contain annual lamina, akin to annual rings in trees, annual varves in glacial lakes, annual laminations in maar lakes, and annual layers in ice cores, is not new, with annual visible laminae first observed by Allison (1926). Whether a speleothem will contain annual laminae will depend on several factors. Firstly, there needs to be an annual rhythm in the surface climate, for example a seasonal monsoon, the annual migration of the inter-tropical convergence zone (ITCZ) or a seasonal soil moisture deficit. Secondly, this annual rhythm needs to be transferred to the speleothem sample, either directly via interactions between the cave atmosphere and surface climate, or indirectly via groundwater transfer of a surface climate signal. Finally, the speleothem has to be located in such a way that it is sensitive to the annual climate variation. For example, not so deep such that excessive smoothing of the annual climate signal by stored groundwater

1 School of Geography, Earth and Environmental Sciences, The University of Birmingham, Birmingham, B15 2TT, UK. 2 School of Environment and Development, The University of Manchester, PO Box 88, Manchester, M60 1QD

3 Laboratoire des Sciences du Climat et de l'Environnement, LSCE/IPSL UMR CEA-CNRS-UVSQ 1572, Bat 701 L'Orme des Merisiers CEA Saclay, 91191 Gif sur Yvette cedex, France. 4 NERC Isotope Geosciences Laboratory, British Geological Survey, Keyworth, Nottingham, NG12 5GG removes the annual signal, nor so close to the surface that sub-annual events dominate over annual ones. Where all three of these cases are true, then annually laminated stalagmites should be expected to be found in the geological record, with an annual lamina width in the range of 10 to $1000 \mu \mathrm{m}$, depending on climatic and geological controls. The stronger the surface annual climate forcing, the more likely that annually laminated stalagmites will be formed over other deposition types. Likewise, in the majority of speleothems, all three requirements for annual lamina formation are not met, and therefore within an individual cave, speleothems can preserve a wide range of laminated and non-laminated forms.

Historically speaking, after the first observations by Allison (1926), the next advance was the first radiometric demonstration of annual visible laminae in a speleothem from the USA in 1960 (Broecker et al., 1960, based on earlier observations of Orr (1952)). Subsequently, the concept of annual rhythms preserved in speleothems was again lost for around 30 years. Data presented by Shopov in the late 1980s suggested that speleothem fluorescence time series might demonstrate an annual periodicity, although no radiometric data was available to confirm this (Shopov et al., 1989). In 1992, Genty (1992) also demonstrated annual visible laminae in some European stalagmites, and Baker et al.(1993) confirmed annual fluorescent laminae in a Scottish stalagmite. Subsequent to these works, the possibility of visible and fluorescent annual lamina deposition 
in stalagmites became increasingly widely accepted. Furthermore, in 1994, Railsback et al.demonstrated annual calcite-aragonite couplets in stalagmites from E Africa (Railsback et al., 1994), and Roberts et al.(1998) demonstrated the presence of annual trace element cycles in speleothems, distinctive parts of which were found to coincide with physical laminae (Huang et al., 2001; Fairchild et al., 2001). Philosophically, trace element variations should also be classified as laminae since lamination reflects a change in chemical composition that is made visible by a physical process of imaging and a variety of forms of chemical mapping (e.g. by synchrotron radiation, backscattered electron imaging) are available, analogous with the use of visible or ultraviolet illumination to detect the property (Figure 1). Today, all of these lamina types are utilised, both as a chronological tool and as a palaeoclimate proxy in their own right.

This review firstly describes the four types of annual laminae found within speleothems, namely: fluorescent laminae formed by annual variations in organic matter flux; visible or petrographic laminae, formed by annual variations in calcite texture or fabric; calcite-aragonite couplets; and finally trace element laminae. We then review the methods available to confirm the annual nature, or otherwise, of lamina deposition. Thirdly, we consider the use of annual laminae in chronology building, with particular relevance to palaeoclimate reconstructions, before finally we consider the use of annual lamina width as a palaeoclimate proxy.

\section{LAMINA TYPES}

Four main kinds of stalagmite laminae from widespread global locations have been reported. Although these laminae types are not mutually exclusive and individual stalagmites can exhibit two or three types of laminae within their growth, we consider each lamina type in turn, making particular reference their formation processes.

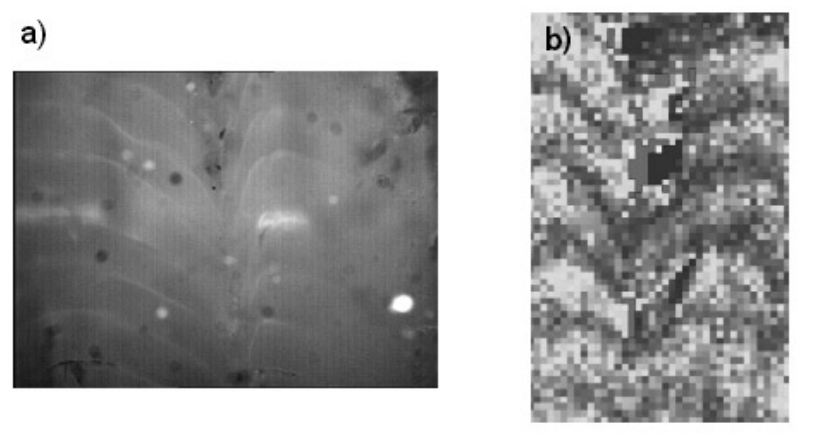

Fig. 1. (a) annual fluorescent banding within stalagmite SU967, Tartair Cave (as described in Proctor et al., 2000) using UV fluorescence; zig-zag growth zones are spaced at around $100 \mu \mathrm{m}$ b) X-ray mapping of $\mathrm{Sr}$ from a similar part of the sample using synchrotron radiation (Fuller, 2006). The Sr image utilizes La radiation using similar analytical conditions to that described by Frisia et al. (2005). The darker (low Sr) zones are equivalent to the fluorescent zones in (a). Resolution is $4 \mu \mathrm{m}$ per pixel. Note: Images show different positions along the growth axis of stalagmite SU967.

\section{Fluorescent Laminae}

Stalagmite fluorescence is caused by the intrinsic fluorescence of natural organic matter, which causes the majority of UV excited fluorescence in cave calcites (Lauritzen et al., 1986; White and Brennan, 1989). Annual fluorescent laminae require annual fluxes of this fluorescent material from the overlying soil onto the stalagmite. Fluorescent laminae have been reported in speleothems from NW Scotland (Baker et al.1993; Proctor et al., 2000; 2002), England (Baker et al., 1999a), Italy (Huang et al., 2001), Belgium (Genty et al., 1997a), eastern Europe and N America (Shopov et al., 1994), Ireland (Ribes et al., 2000), N Norway (Linge et al., 2001) and eastern China (Tan et al. 1999). Examples of fluorescent laminae can be seen in Figure 2. This fluorescence is normally observed using a mercury light source to provide the necessary UV excitation, with emitted fluorescence observed using reflected light microscopy. Excitation, emission and barrier filters control the wavelengths of excitation and emission. Exceptionally, other methods have been used, including transmitted laser excitation

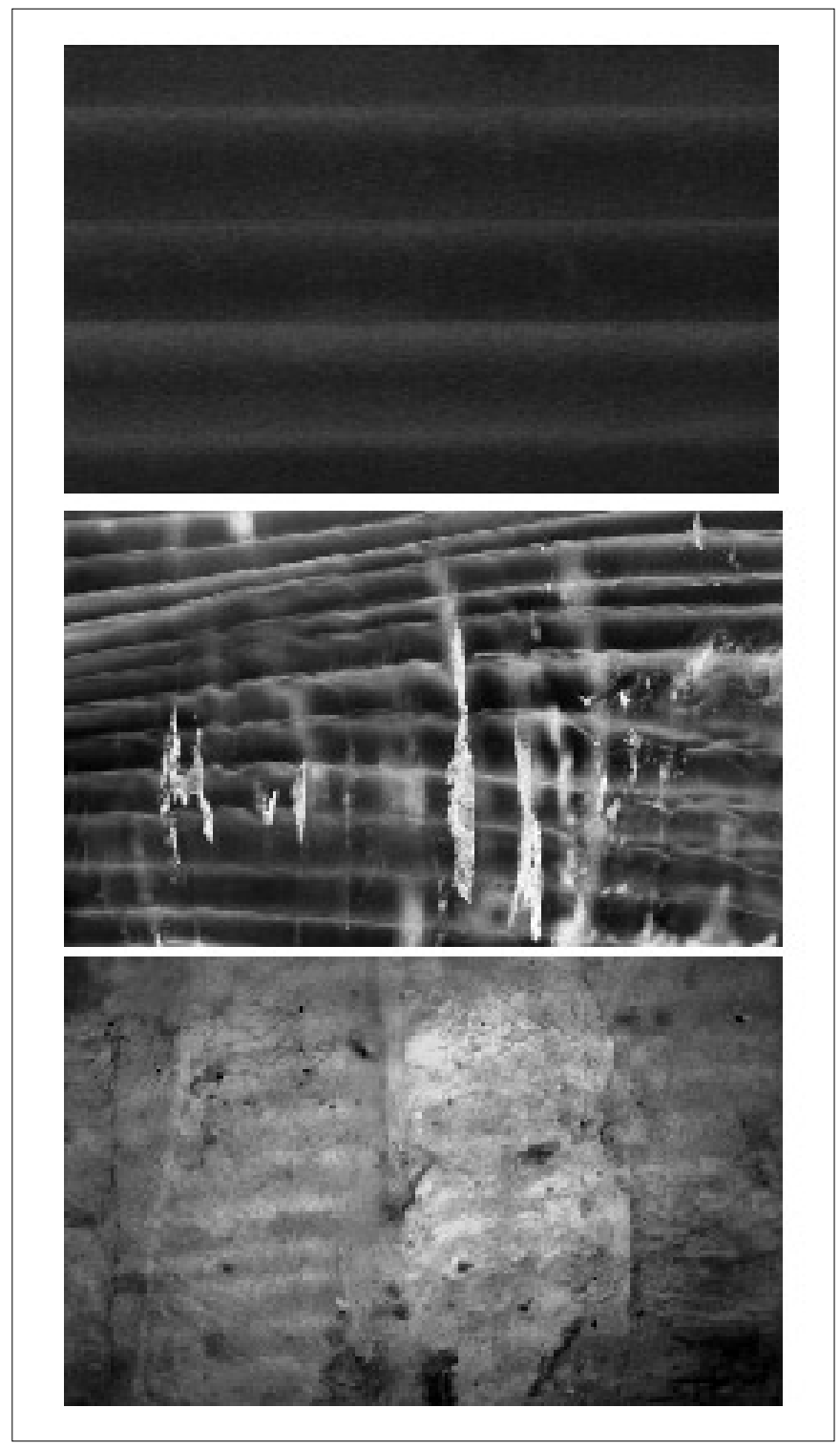

Fig. 2. Examples of fluorescent laminae (1) Shihua Cave, Beijing (2) Stalagmite ER-77, Ernesto Cave, Italy. x5 magnification (3) Stalagmite SU-03-2, Uamh an Tartair, Scotland, x10 magnification. 
(Shopov et al., 2004) and confocal microscopy (Ribes et al., 2000).

Our understanding of stalagmite fluorescence properties has improved in recent years for several reasons. Firstly, research into the fluorescent properties of modern rivers and groundwaters has enhanced our understanding of the sources of fluorescence observed in stalagmites. Stalagmite fluorescence is dominated by fluorescence at excitation wavelengths between 300 and $420 \mathrm{~nm}$ and emission between 400 and $480 \mathrm{~nm}$. Fluorescence in this region of optical space in modern soil, river and groundwater samples is derived from 'humic' substances - relatively high molecular weight and aromatic dissolved organic matter (Mournier et al., 1999; Coble, 1996; Baker, 2001; Hudson et al., 2007). Variations in the emission wavelength of this fluorescence centre to higher wavelengths has been shown to be due to an increase in molecular weight or aromacity (Coble, 1996; Del Vecchio and Blough, 2002), and the intensity of this fluorophore correlates strongly with dissolved organic carbon concentration in modern systems (e.g. Baker and Spencer, 2004), often with seasonal climate induced fluctuations. In arctic and alpine areas, the seasonal peak of dissolved organic carbon in rivers occurs in spring, due to snowmelt (Boyer et al., 1997), whereas in the temperate maritime regions of Europe, it falls in autumn, after the summer period of soil moisture deficit (Worrall et al., 2005). This is the case in NW Scotland where ombrotrophic blanket peat overlies caves in which stalagmites are actively being deposited (Charman et al., 2001). Fluorescent laminae are associated with autumn rainfall which flushes humic acid, which is resident in the peat, to the subsurface (Proctor et al.2000). In monsoon regions the DOC peak occurs at the time of monsoon rains (Gao et al., 2002). In all cases, therefore, increases in dissolved organic matter are driven by increases in discharge. These modern surface process studies confirm that dissolved organic matter is the most likely source of fluorescence in stalagmites (White and Brennan, 1989), the likelihood of seasonal variations in fluorescence intensity depending on climate regime (Tan et al., 2006), as well as a relationship between fluorescence wavelength and dissolved organic matter composition (Baker et al., 1998; Perette et al., 2005).

\section{Visible laminae}

Laminae can be observed in calcite stalagmites using conventional transmission and reflection light microscopy, as reviewed by Genty (1992, 1993). Laminae observed under visible light have been reported from regions as diverse as New Mexico (Polyak and Asmerom, 2001), Brazil (Bertaux et al., 2002; Soubies et al., 2005), France (Genty, 1993, and references cited therein; Genty et al., 1997a, b), Belgium (Genty and Quinif, 1996), Germany (Wurth et al., 2003), Italian Alps (Frisia et al., 2000), China (Tan et al., 1997; Paulsen et al., 2003; Kong et al.2003), India (Yadava et al., 2004), Oman (Burns et al., 2002), Ethiopia (Asrat et al., 2007; Baker et al., 2007), and South Pacific (Rasbury and Aharon, 2006).
Figure 3 presents examples of visible laminae from our unpublished work in Turkey. Visible laminae require a regular (often seasonal) alternation of the arrangement in space of crystals with a well-defined morphology (texture or fabric; Kendall and Broughton, 1978; Onac, 1997; Frisia et al., 2000), referred to by Chinese researchers as the "South China type" (contrasting with the "North China type" of infiltration laminae which often, but not always, coincide with UV laminae). Another description of laminae in the literature is an alternation from 'dark compact calcite (DCC) to white porous calcite (WPC) as defined by Genty (1992), Genty, and Quinif (1996).

The wider geographic range of visible laminae in comparison to fluorescent laminae reflects the wider range of processes responsible for their formation. These processes might include one or both of the following: (1) Seasonal variations in drip rate. For example, visible laminae observed in Ethiopian stalagmites are defined by zones with multiple thin (micron-scale) laminae represented by impurities (opaque in transmitted light) and within elongate columnar fabric perpendicular to growth (Baker et al., 2007). Where most strongly developed they drape crystallite surfaces that occasionally show some dissolution features: these surfaces occur annually during the winter dry season due to drip cessation, or very slow drip rates. The groups of opaque laminae compare with infiltration laminae characterized by the input of detrital and colloidal material during periods of infiltration (Borsato et al. 2007) in seasonally high flows. (2) Seasonal variations in drip water supersaturation and/or cave climatology (relative humidity, $\mathrm{CO}_{2}$ ). For example, stalagmites from wellventilated caves (e.g. Spötl et al., 2005), or from locations close to cave entrances, may experience seasonal variations in cave climate which in turn could lead to seasonal variations in calcite texture or fabric due to changes in drip water supersaturation $\left(\mathrm{CO}_{2}\right)$ or probability of evaporative calcite formation. Therefore, the precise controls on visible laminae are poorly understood, although there is a much better understanding of the crystal fabrics that form annually laminated stalagmites; an understanding of the formation mechanism of which can explain the conditions under which the crystallites in each laminae form (Frisia et al., 2000).

Recent work by Jex et al. (2008) uses hyperspectral imaging to analyse visibly laminated stalagmites from two caves (Karaca Cave and Akçakale Cave) in north east Turkey. Hyperspectral imaging has been used successfully in geological and mineral mapping, air and water pollution tracing, and medical imaging, but is a new technique in the area of stalagmite research. Potentially it has many advantages over standard optical imaging techniques in terms of the detail of information that can be obtained from a single image capture process (Jex et al., 2008). Standard imaging techniques utilising either a flat bed scanner or digital camera-microscope use only 3 filters to capture all light reflected in 3 broad bands of wavelengths; the red, green and blue. The final image produced from these standard optical techniques 

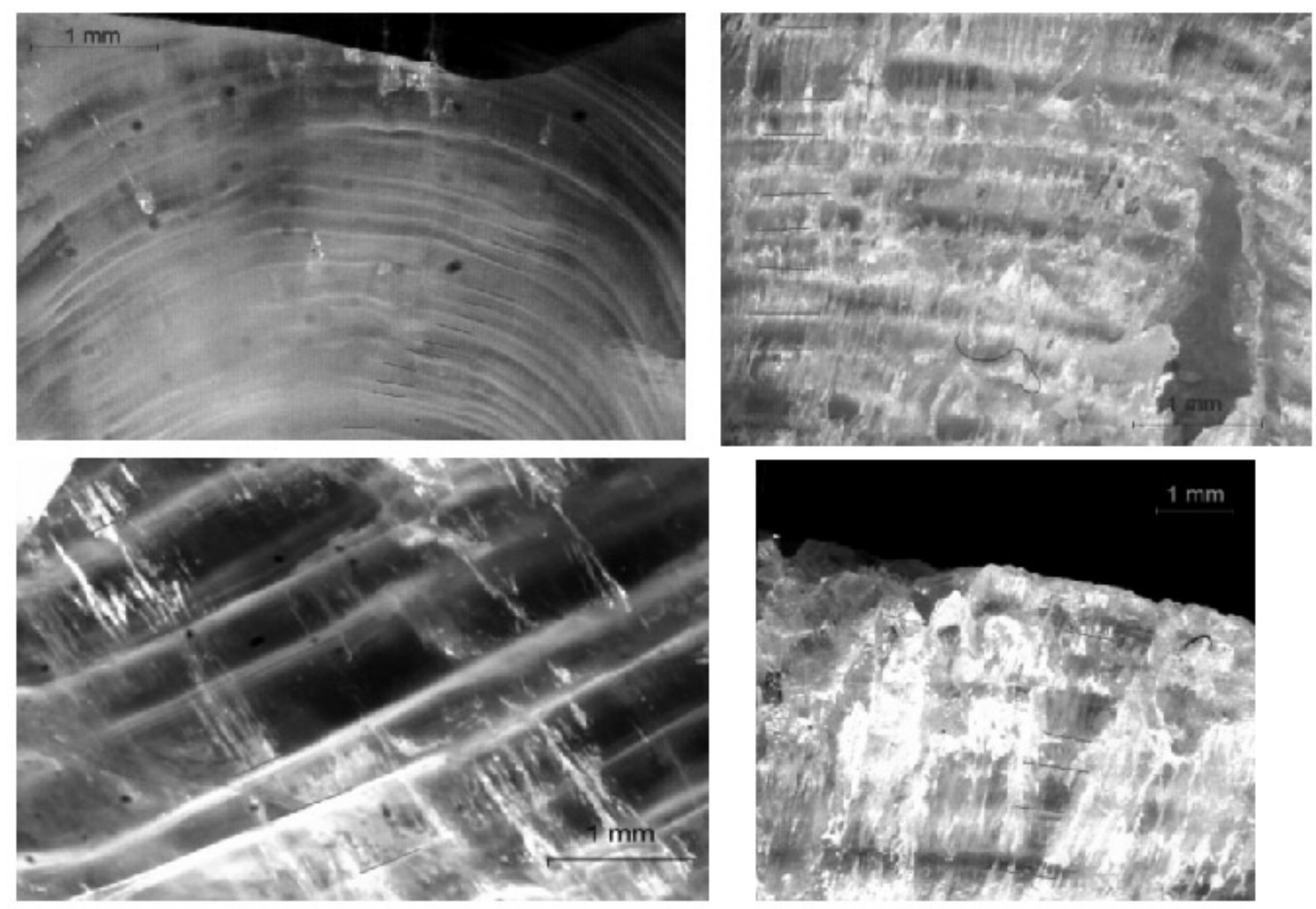

Fig. 3. Examples of visible annual laminations in two stalagmites from Akçakale Cave Gümüşhane province, north east Turkey: The top two images are from stalagmite "Colin", dated by U-Th as growing over the last 650 years. The image on the top left is taken from the lower section of the stalagmite ( 600yrs BP), demonstrating growth rates of $\sim 0.1-0.2 \mathrm{~mm} \mathrm{yr}^{-1}$ in generally compact calcite. The top right is from the upper section of the same stalagmite, around $\sim 30 \mathrm{yrs} \mathrm{BP}$, by which time the stalagmite records growth rates in the range of $\sim 0.3$ to $0.7 \mathrm{~mm}^{-1} \mathrm{in} \mathrm{generally} \mathrm{much}^{-1}$ more porous calcite fabric. The bottom two images are of "2pac", another modern stalagmite growing continuously over the last 500 years. Bottom left shows visible laminations at $\sim 140 \mathrm{yrs} B P$, with growth rates in the range of $\sim 0.5$ to $0.7 \mathrm{~mm} \mathrm{yr}^{-1}$ in generally compact calcite, whereas bottom right again shows a shift to more porous calcite with visible laminations of growth rates $\sim 0.7$ to $1.1 \mathrm{~mm} \mathrm{yr}^{-1}$ deposited over at least the last 40 years up until the date of collection in 2004 AD. The change in calcite fabric in both samples is likely due to a change in hydrology, possibly caused be a change in land-use.

reflects this and is composed of only 3 image 'slices'. In contrast a hyperspectral image is composed of several hundred slices with each slice being as narrow as a few nanometers. Thus, hyperspectral imaging is able to offer a faster, less contentious, and more accurate way of identifying, separating and counting growth lamina which ultimately reduces uncertainty and error. Black and white images of two annually laminated stalagmites growing continuously over the last $\sim 650$ years from Akçakale Cave, Turkey, are shown in Figure 4 (details as in Figure 3). These images were obtained at $5 \mathrm{~nm}$ spectral intervals and show both WPC and DCC sections of lamina. The reflectance spectra $\mathrm{H}_{\mathrm{H}}$ obtained from these images are most different between $\sim 40$ to $590 \mathrm{~nm}$ in stalagmite $\mathrm{C}$ and between $\sim 40$ to $680 \mathrm{~nm}$ in stalagmite $2 \mathrm{p}$. Thus, for the purposes of lamina counting, focussing on these wavelengths will most clearly distinguish between different lamina.

\section{Calcite-aragonite couplets}

In some cave environments, seasonal alternations of aragonite and calcite growth layers have been reported, most notably from north western Botswana (Railsback et al. 1994) and Nepal (Denniston et al., 2000). Again, the processes generating this lamina type are poorly understood: many factors have been implicated in the formation of aragonitic stalagmites (including temperature, drip rate and dissolved magnesium concentrations; see review in Frisia et al., 2002) and by inference, calcite-aragonitic laminated stalagmites require such a threshold to be crossed with regular alternations.

\section{Trace element laminae}

Fairchild et al. (2007) argue that annual trace element variations represent a more general expression of the phenomena that give rise to fluorescent or visible laminae and appear to be near-universally present where looked for at an appropriate spatial scale and with suitably sensitive techniques. One reason for this is the recognition that fluorescent organic matter is known to be associated with a suite of trace elements that appear to be readily transported in colloidal form (Borsato et al., 2007). Another is that the composition 

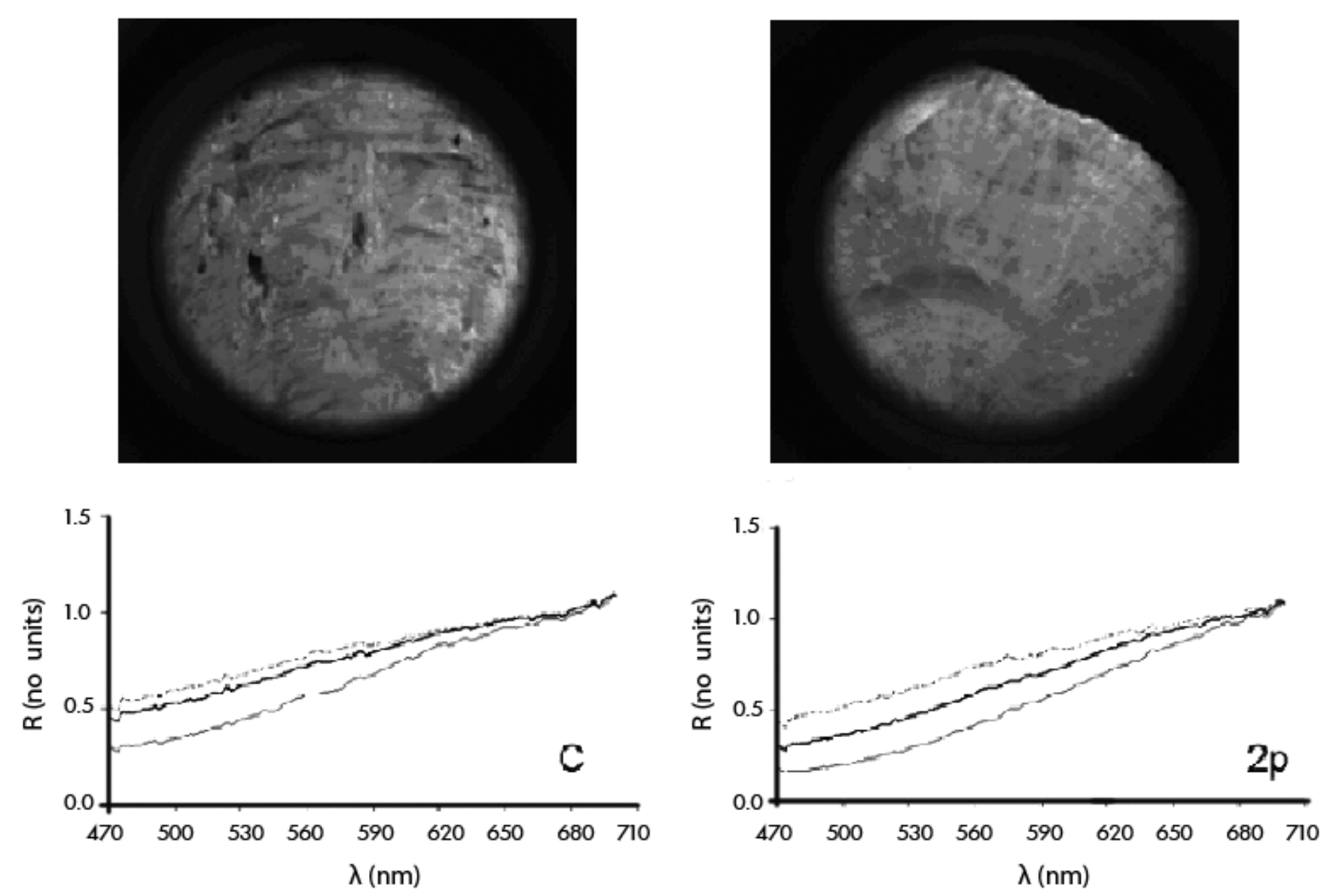

Fig. 4: Greyscale image and corresponding reflectance SpectraH (shown directly underneath image) obtained from areas of WPC (dotted line) and DCC (solid narrow line) in Colin (C) (left) and 2-Pac (2p) (right) from Akçakale cave. The solid thick line represents the "average" spectraH of the whole image. $R=$ Reflectance Intensity (no units). Field of view is 3 ".

of carbonate minerals is a sensitive function of environmental conditions (e.g. supersaturation, temperature, fluid trace composition), responding via changes in growth rate and crystallographic microstructure that inevitably lead to zonation. In addition to seasonal variations in hydrological behaviour, the annual temperature cycle also imposes a signal that may be most strongly expressed as a change in cave air circulation, which in turn affects cave air $\mathrm{PCO}_{2}$ and $\mathrm{CaCO}_{3}$ mineral supersaturation.

\section{TESTING THAT LAMINAE ARE ANNUAL}

As discussed in the previous section, many processes may generate laminae within speleothems, not all of which are annual in their timing. In regions where there is a dominant annual climate forcing, e.g. monsoonal or equatorial regions, and with an observation of regular and continuous lamina sequences in speleothems, then annual lamina deposition might be presumed to be the dominant mode of formation. In contrast, in all regions of the world, both supra-annual and subannual laminae are also possible modes of formation. In some climate regimes, sub-annual laminae may be the typical deposition mode. For example, in an Arctic stalagmite from N Norway, Linge et al.(2001) demonstrated from a TIMS uranium-thorium dated sample that statistically 1.4 laminae occurred each year. Here, the 'annual' lamina set was an intensely fluorescent and regular lamina, hypothesized to be the regular spring snowmelt, which in some years was followed by a weakly fluorescent lamina formed in autumn in years where summer was warm enough to produce fresh organic matter and autumn mild enough for this to be transported to the groundwater system before the winter snowpack developed. In contrast, Asrat et al.(2007) report annual laminae from a stalagmite in Ethiopia. This region has two rain seasons, one in early spring and the other in summer; however, groundwater mixing of the two rain seasons means that annual lamina deposition is typical for the region. Sub-annual laminae are also more likely to occur in speleothems that are found closer to the ground surface and which exhibit less groundwater mixing. Supra-annual laminae can be hypothesised to occur when speleothem formation is affected by an extreme event, or in samples that are particularly sensitive to decadal to centennial climate variability. However, such laminae are poorly studied. Figure 5 presents supra-annual laminae from stalagmites from NE Turkey.

The two main drivers for studying annual laminae in speleothems are their use in chronology building and the use of lamina widths as a climate proxy. To use either, it first has to be demonstrated that the laminae are indeed annual. Four methods to do that are recommended. 


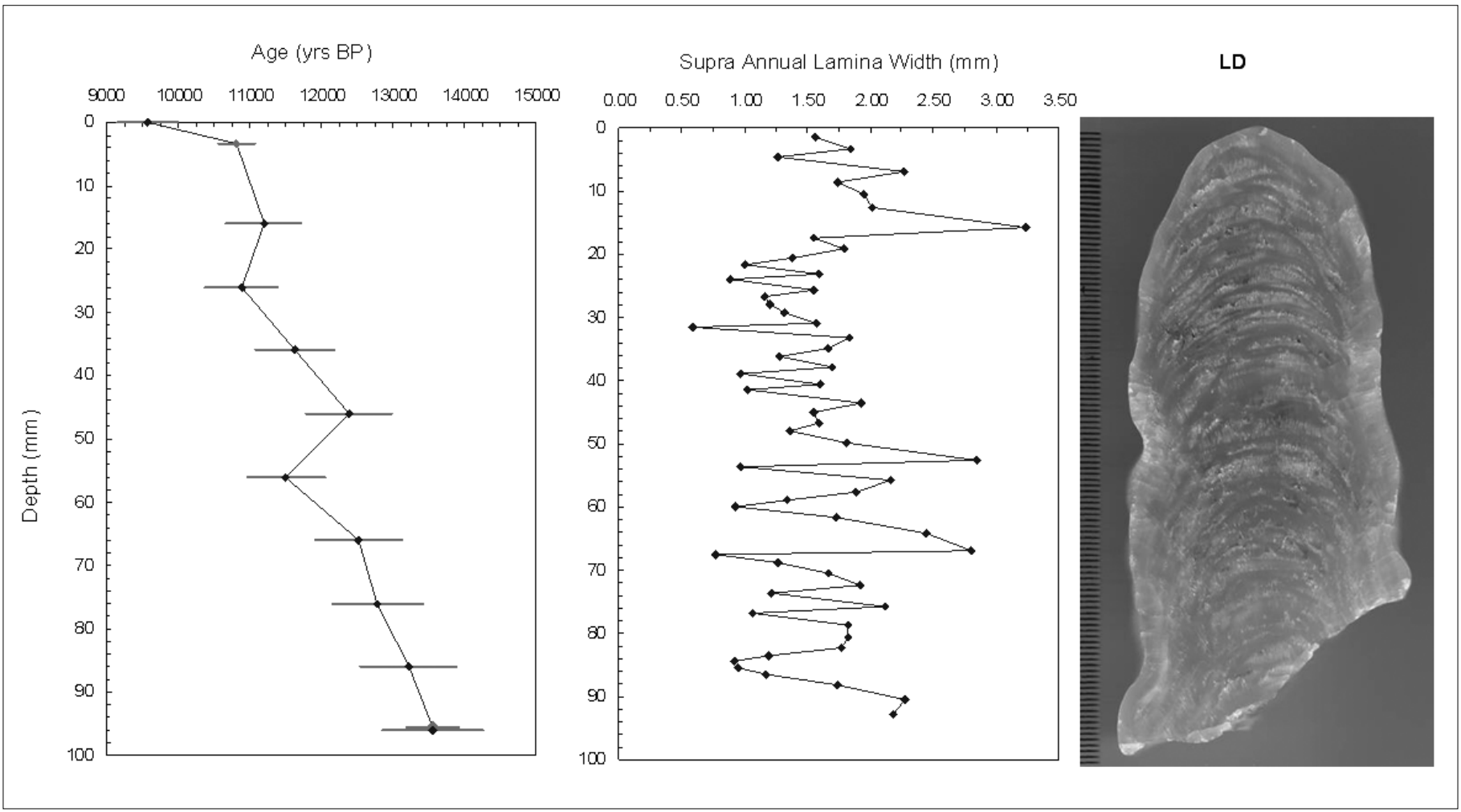

Figure 5. Supra Annual Laminations: example of a soda straw fed Stalagmite from NE Turkey. Lower Dikit (LD) from Karaca cave in the Gümüşhane province of north east Turkey is characterised by generally colourless calcite of a porous fabric with continuous visible lamina, typically measured at $1.60 \pm 0.53 \mathrm{~mm}$. Growth rates within this range can not be predicted from modern drip-water electrical conductivity and cave temperature $\left(10{ }^{\circ} \mathrm{C}\right)$ (Dreybrodt, 1988). U-Series and $14 \mathrm{C}$ dates with a presumed dead carbon percentage of $20 \%$ showed the sample to have started growing 13550 $\pm 375 \mathrm{yrs}$ BP and to have ceased growing 4000 years later at around $9565 \pm 425 \mathrm{yrs}$, suggesting that these laminations are not annual but supraannual, occurring every $\sim 69$ years.

\section{Comparison with radiometric ages}

One method that has been widely reported is to compare the number of layer counts between well-dated layers. This might be by comparing radioisotope dates and the interval of time dated, through the difference between uranium-thorium age determinations (e.g. Baker et al., 1993; Asrat et al., 2007; Polyak and Amserom, 2001; Asmerom and Polyak, 2004), or radiocarbon age determinations (making the assumption of a constant 'dead' or geological carbon contribution, e.g. Broecker et al., 1960). The age error on uranium-thorium analyses determines the age range of stalagmites for which the annual nature of laminae can be confirmed: with a typical age error of around 1\% then 100 laminae between $1,000 \pm 10$ and $1,100 \pm 11$ yrs BP can be demonstrated to be annual, but 500 laminae between $30,000 \pm 300$ and $30,500 \pm 300$ can not. Similarly, the use of radiocarbon depends on a constant dead carbon proportion (which has shown to be typically 10-15 $\pm 5 \%$ in Western Europe samples; Genty and Massault (1997)) and position on the radiocarbon calibration curve.

An alternative radiometric methodology for use in modern samples is to compare the number of laminae with the ${ }^{14} \mathrm{C}$ bomb carbon signature that provides a useful marker of the early AD1960s (Genty et al., 1998). This is only suitable for samples with a relatively short soil and groundwater storage of ${ }^{14} \mathrm{C}$, as the atmospheric bomb carbon peak is smoothed and dampened by soil storage. Many stalagmites fail to exhibit a ${ }^{14} \mathrm{C}$ peak at $>100$ percent modern carbon, although a rise in ${ }^{14} \mathrm{C}$ towards the top of the speleothems suggests modern deposition, it prevents the use of the bomb carbon peak as a time marker to confirm annual lamina deposition. Additional techniques that have yet to be widely utilised also include ${ }^{226} \mathrm{Ra}$ and ${ }^{210} \mathrm{~Pb}$ dating of young samples (Baskaran and Iliffe, 1993; Paulsen et al., 2003; Condomines and Rihs, 2006).

\section{Laminae counting between event horizons}

Another technique is to use markers of a known event in the cave. This could be counting the number of laminae accumulated upon cave infrastructure placed during conversion to tourist use (e.g. growth upon a boardwalk, Treble et al., 2003), or the number of laminae deposited upon archaeological deposits of known age, or using event markers, such as the explosion soot marker which occurred in the Postojna cave in 1943 (Genty et al., 1998)). The event may even be the artificial construction of a cave or mine (Orr, 1952; Baker and Smart, 1995).

\section{Cave monitoring}

The cave-based observation of a dominant annual periodicity in either drip water chemistry or cave climate provides another line of evidence that speleothems laminae are annual. For annual fluorescent laminae, one would expect to observe an annual periodicity in drip water fluorescent organic matter or dissolved organic carbon. For example, Ban et al.(2008) demonstrate a strong seasonality in dissolved organic carbon in Shihua Cave, Beijing, where stalagmites exhibit continuous fluorescent laminae (Figure 6). A similar experiment measuring drip water fluorescence of multiple drips 


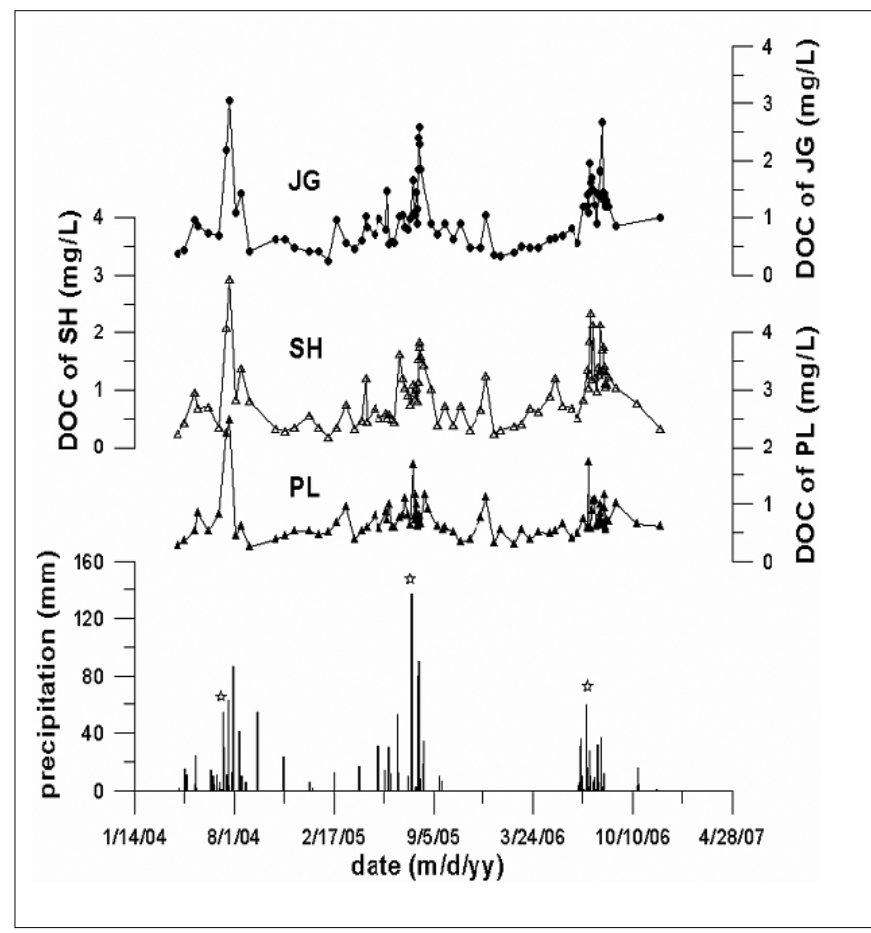

Fig. 6. Rainfall amount and the intra- and inter-annual variation of dissolved organic carbon (DOC, unit: $\mathrm{mg} \mathrm{L}^{-1}$ ) in three drip sites at Shihua Cave, Beijing, during the period April 2003 and December 2006. The important rainfall events causing the increase of DOC concentration in drip water are marked with stars. (No rainfall data available January to May 2006). From Ban et al. (2008)

over a hydrological year at the Brown's Folly Mine site in England (Baker et al., 1999b) also observed an increase in fluorescent dissolved material during the period of hydrologically effective precipitation in autumn. In the case of annual visible lamina deposition, or aragonitecalcite couplets, one would expect to observe seasonal variations in either drip rate, drip water supersaturation (c.f. Frisia et al., 2000, 2002) or cave climatology. Strong seasonal variability in these parameters has been observed in many caves; for example, strong seasonality in drip rate (Genty and Deflandre, 1998), in major elements in several caves across Europe: Genty et al., (2001) and in cave climate (Spötl et al, 2005). Cave monitoring may also be utilised to demonstrate annual variations in drip water trace elements.

An alternative cave monitoring experiment that can be used is to carry out in-situ calcite growth experiments to recognize the annual formation of laminae observed in stalagmites. Such experiments have been made in the Villars Cave (SW-France) by putting tiles under active stalactites (Figure 7). In this figure, a tile which was deposited between the 22/8/1996 and 26/9/2000 shows four alternations of WPC/DCC on a maximum height of $7 \mathrm{~mm}$. The fast growth rate is due to the high $\mathrm{Ca}^{2+}$ concentration of the seepage water $(>100$ ppm), the fast drip rate (2-30s / drip) and the flat shape of the tile (permitting a high water film thickness). Frisia et al.(2000) report similar experiments within the Grotta di Ernesto to confirm that laminae were annual.

\section{Comparing lamina width with theoretical predictions}

A final test of the annual nature of laminae is to compare the observed lamina width with that

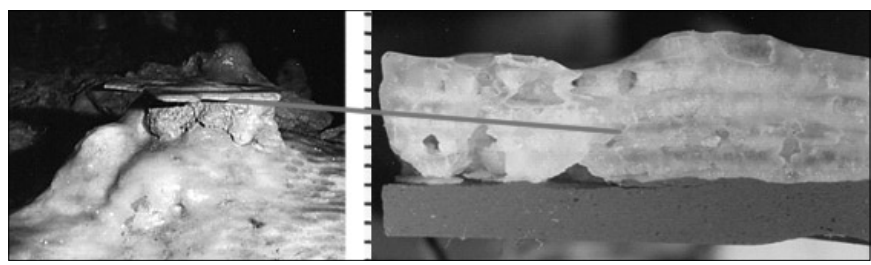

Fig. 7. Example of a modern deposition experiment, Grotte de Villars, Dordogne. Top left shows a tile placed on top of an actively forming stalagmite. Lower right picture shows the four laminae formed during the four years of tile placement. $1 \mathrm{~cm}$ scale bar shown to the left.

theoretically predicted. Through the work of Wolfgang Dreybrodt (Dreybrodt, 1980; 1981; 1988) and Baker et al., (1998) the factors that affect stalagmite growth rate are well understood. The significant determinants are, for a constant and close to atmospheric cave air $\mathrm{pCO}_{2}$, the calcium ion concentration and the temperature of the drip water and the water supply rate (see Spötl et al, (2005) for a case where variable cave air $\mathrm{PCO}_{2}$ is important). Baker et al.(1998) and Genty et al.(2001) demonstrate that there is a good correlation between observed, recent stalagmite growth rate and that theoretically predicted for six caves throughout Europe, with the principal determinant of growth rate being the calcium ion concentration. More recently, Asrat et al.(2007) demonstrate agreement between theoretically predicted growth rates from dripwater chemistry and actual lamina widths, as well as between the number of laminae between radiometric (U-Th) analyses in an Ethiopian stalagmite. Assuming that the modern day drip waters can be related to those that are forming or have formed laminated stalagmites, measurements of calcium concentration of modern drip waters in caves where laminated stalagmites are present can also give an indication as to whether laminae are annual.

\section{STALAGMITE LAMINA-CHRONOLOGY}

Annually laminated stalagmites have widespread chronological applications. The simplest is to provide a precise age-depth model, providing the age control for other stalagmite climate parameters. Examples of the application of annual laminae to provide an age-depth model include Burns et al.(2002), who use annual laminae both to construct an age-depth model, as well as a climate proxy via lamina width variations, in a stalagmite from Oman that has deposited for the last 780 years. Paulsen et al. (2003) observed visible lamina in the last 150 years of deposition of a Chinese stalagmite and used laminae and ${ }^{210} \mathrm{~Pb}$ to confirm the recent depositional history of the sample. Baker et al.(2007) use laminae to constrain $\delta^{18} \mathrm{O}$ over the last 100 years in Ethiopian stalagmites in order to compare $\delta^{18} \mathrm{O}$ and lamina width with instrumental climate data.

A second application is to determine the duration of an event preserved within a speleothem sample. Baldini et al.(2002) was the first attempt to estimate the duration of a significant climatic event (at around $8.2 \mathrm{ka}$ ) by counting trace element laminae (but see Fairchild et al., 2006). McMillan et al. (2005) used annual trace element laminae in a two stalagmites from southern France both to establish an anomaly in 
mean composition as representing an arid event, and also to estimate its duration (ca. 750-850 A.D).

Counting errors from annual lamina counts are typically quoted at $1-3 \%$, of the same order of magnitude as TIMS U-Th analyses for Late Quaternary age samples. For example, Baker et al.(2002) compare a 1000 year lamina count with documentary climate data, and demonstrate an age error of $<4$ years over the last 310 years of the record. Also important for understanding age-depth relationships is that annual lamina series demonstrate that stalagmite deposition is often persistent, non-stationary and non-linear, insights which can improve our understanding of stalagmite chronologies. Figure 8 presents four long continuous lamina chronologies for samples that have been deposited over the last 1000 years. All exhibit persistence within the lamina series (i.e. there is a temporal autocorrelation in lamina width series to long lag times, such that the growth rate at year $\mathrm{t}+\mathrm{n}$ shows some correlation with that at time $\mathrm{t}$ ). Nonstationarity in the series is evident by the fact that variability of lamina thickness varies through time, often in proportion to growth rate (most samples exhibit greater growth rate variability at faster growth rates; for more detail see Tan et al., 2006, Figure 11). The White neural network test for nonlinearity shows

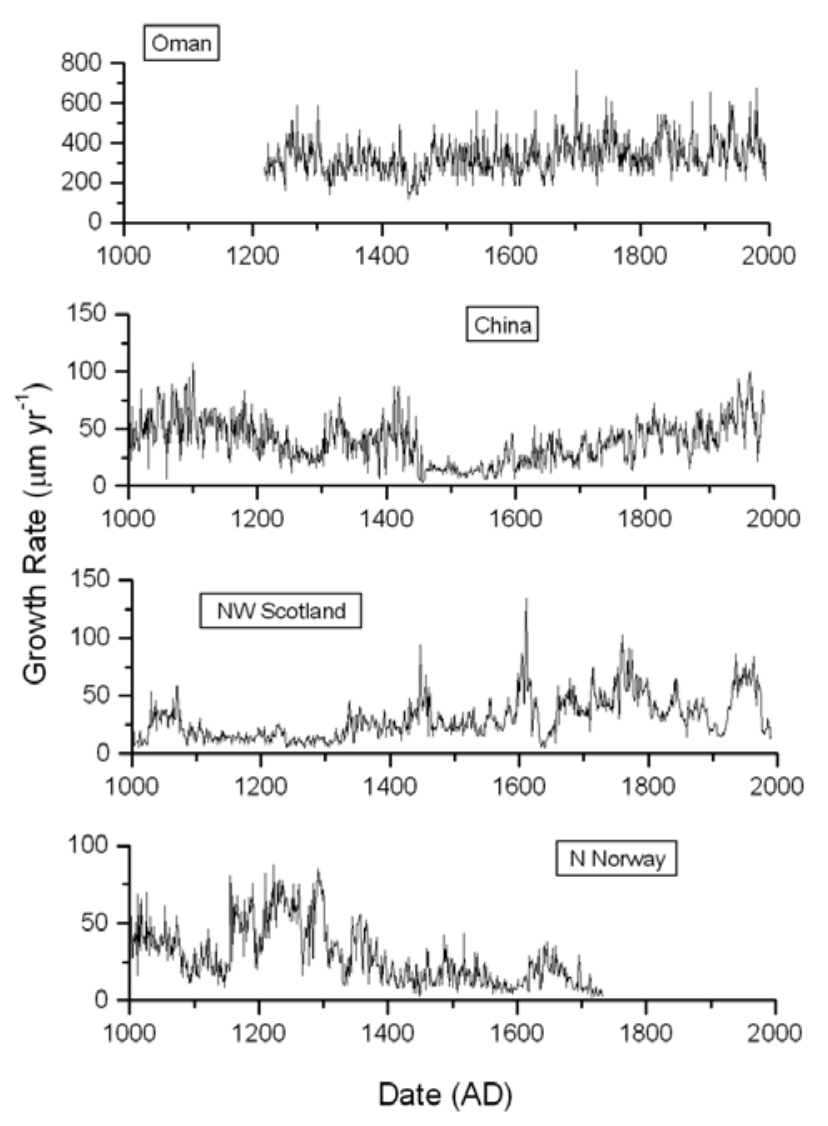

Fig. 8.Continous annual lamina chronologies for four stalagmites growing over the last 1000 years. From top to base: Oman (Burns et al., 2002), China (Tan et al., 2003), Scotland (Proctor et al., 2001), and Norway (Linge et al., 2001). All four are statistically nonlinear, Oman at the $95 \%$ confidence level, other series at the $99 \%$ confidence level (White's test for non linearity). that all four series are statistically non-linear: the long-range persistence is interspersed with sudden nonlinear jumps to higher annual growth which occur at irregular intervals, confounding the predictability of speleothem growth. Consequently, the combination of these statistical properties suggests that, for annually laminated stalagmites at least, linear agedepth models based on U-Th analyses may not be appropriate in all cases.

A combination of continuous annual laminae and radiometric ages leads to the possibility of improving the uncertainties associated with radiometric analyses. Similar to using isochron dating techniques, with multiple radiometric analyses at the same time period, a series of radiometric analyses through time along a continuously annually laminated sequence can be tied to that lamina chronology. This laminae-tuning' approach introduces flexibility to the U-Th dates by assuming non-constancy of the detrital activity ratio across the stalagmite deposition period. Current values of the initial activity ratio vary widely across studies and are presumed to be invariant with time. However, by allowing a range of values for the activity ratio for each radiometric date it becomes possible to align ages which are discordant with the laminae or eliminate unusual behaviour, such as age reversals. An example from such an approach can be found in Asrat et al.(2007), where 6 U-Th analyses over a $\sim 500$ year lamina sequence $\sim 5 \mathrm{ka}$ before present were tied to the lamina chronology to improve the estimation of the date of deposition.

Annually laminated stalagmites are of particular importance when stalagmites are used in highresolution palaeoclimate studies. For example, a standard technique is to compare stalagmite climate parameter(s) with instrumental climate data for the last $\sim 100$ years. Given the limited time period available for calibration, the potential for a non-linear age-depth model, and the difficulties in obtaining precise U-Th analyses over this time period when little ${ }^{230} \mathrm{Th}$ has been produced by decay, an annual lamina chronology is essential. Moberg et al.(2005) used both a U-Th dated ${ }^{18} \mathrm{O}$ stalagmite record as well as a lamina width climate record in a multi-proxy reconstruction of last 1000 year climate. However uncertainties associated with the top U-Th ages used to constrain the ${ }^{18} \mathrm{O}$ record were of the same order of magnitude as the instrumental calibration period, introducing additional uncertainty into the climate reconstruction.

\section{STALAGMITE LAMINA-CLIMATOLOGY}

If the change in annual lamina thickness can reflect surface climate variations through the relationship between growth rate and climatic and geochemical parameters, as discussed in Dreybrodt (1980; 1981; 1988); Baker et al., (1998); Genty and Quinif, (1996); and Genty et al.(2001), then the methodology of quantitatively reconstructing climate from stalagmite growth layers can be defined as a stalagmite laminaclimatology. Published examples where a quantified climate signal has been obtained from stalagmite lamina thickness include Brook et al.(1999), Proctor 
et al.(2000, 2002), Burns et al.(2002); Tan et al.(2003), Frisia et al.(2003), Smith et al.(2006), Rasbury and Aharon, (2006), and Baker et al.(2007). In these studies, stalagmite deposition has been over the modern period of instrumental records, from regions as diverse as Madagascar (Brook et al, 1999), Scotland (Proctor et al., 2000; 2002), Italy (Frisia et al., 2003), Oman (Burns et al., 2002), China (Tan et al., 2003), South Pacific (Rasbury and Ahron, 2006) and Ethiopia (Baker et al.2007), and the records used are all from visible or fluorescent laminae.

In order to use annual lamina width as a climate proxy, it has to be assumed that the annual lamina thickness at any one point on a stalagmite is representative of the sample as a whole. Therefore, stalagmites with a regular 'candlestick' shape are preferred, because in more irregularly shaped samples, within lamina variability of thickness may be greater than that between lamina variability. Additionally, the basal section of a sample may have a lamina thickness that is a product of deposit geometry (for example, the angle of slope upon which the stalagmite is growing, or movement or slumping of the growing stalagmite into soft sediment), rather than drip water quantity or quality. Finally, over the whole period of stalagmite growth, lamina thickness may demonstrate a long term trend of either increasing or decreasing growth rate. Such trends might be due to local or regional surface climate trends, or related to long term changes in stored groundwater characteristics that can make up a significant proportion of the drip water. Care has to be taken to understand the process(es) generating these long term trends, before the low frequency component of the dataset can be confidently rejected (or accepted).

It is important to recognize that although stalagmites within a cave may show similar lamina width time series, a lack of correlation between stalagmites suggests different sensitivities to climate, due to different filtering of the climate signal by the karst system. Calibration of the lamina width series with instrumental or historical monthly-observed data (rather than annually averaged data) is very useful to understand the precise climate sensitivity of any one stalagmite. For example, in Ethiopia we have considered the climate sensitivity of three lamina width series (Baker et al., 2007 and unpublished data). Figure 9(a) shows that the three stalagmites have similar stratigraphies, with periods of white (colourless) calcite deposition correlating between samples, particularly between 1905 and 1930 and around $1984 \mathrm{AD}$, periods of known drought, in contrast to periods of brown coloured calcite associated with organic matter and deposition under wetter/more humid conditions. Figure 9 (b) shows that the $\delta^{18} \mathrm{O}$ and growth rate of the three stalagmites give different responses to surface climate due to variations in the climate transfer signal. All stalagmites have a climate response that is seasonal; this signal is smoothed by the mixing of event and storage water within the aquifer. Of the three samples, Merc-1 has the greatest variability in $\delta^{18} \mathrm{O}$, due to a greater ratio of event to storage water in this sample. In contrast, Asfa-3 and Bero- 1 respond more to low frequency ('storage') climate. We show that different stalagmites respond to different rain seasons, depending on the relative proportions of spring and summer rains that recharge the stalagmite (Figure 9(c)). For example, stalagmite Asfa- 3 has a growth rate that responds to the amount of summer rain whereas Bero- 1 growth rate and $\delta^{18} \mathrm{O}$ respond to the spring rains. Figure 9(d) presents comparison between instrumental and stalagmite reconstructed rainfall for the two stalagmites within the last 100 years.

Lamina width climatologies can also be used where calibration is not possible, provided a multi-parameter approach is taken. Asrat et al. (2007) compare annual lamina width with $\delta^{18} \mathrm{O}$ and fluorescence wavelength variations in a mid Holocene stalagmite from Ethiopia. Through the use of a multi-parameter approach, the authors were able to distinguish the relative importance of the various parameters in recording cave 'external' (climate, hydrology) and cave 'internal' (e.g. evaporation, degassing) processes. In this case, lamina width reflected the overlying soil conditions and hydrology i.e., behaving as a 'cave external' proxy. A lack of correlation with $\delta^{18} \mathrm{O}$ and $\delta^{13} \mathrm{C}$ isotopes suggested that in this sample these parameters reflected 'within cave' factors such as evaporation or rapid degassing leading to isotope disequilibrium.

In the future, it is envisaged that regional compilations of annual lamina series from stalagmites will be produced which will be similar to tree ring composite records, in which the dominant climate signal can be extracted. Smith et al. (2006) made a first attempt at such an approach, utilising three stalagmite series from the middle latitudes of the Northern hemisphere. While the three stalagmites were formed under diverse climate conditions, temperate (Scotland; Proctor et al., 2000), alpine (Italy; Frisia et al., 2003) and sub-tropical (China; Tan et al., 2003), their layer thickness chronologies were found to contain a common signal. Building on linkages with local climate, which are themselves related to large-scale patterns of climate variation, the inter annual growth variations within the individual stalagmites were combined and allied to the observed hemispheric temperature record to give an up-scaled Northern Hemisphere temperature reconstruction for the past 500 years. Comparisons with a number of other published Northern Hemisphere reconstructions proved favourable (Figure 10a), and while there are a number of data limitations associated with the stalagmite laminae reconstruction as it stands, the calculation of evaluative diagnostic statistics suggest that it may offer a skilful hind cast (e.g. Reduction of Error $=0.304$ ).

By taking advantage of a recently collected laminated stalagmite, also from Uamh an Tartair in north-west Scotland (Fuller, 2006), the Northern Hemisphere reconstruction can be updated to include the additional information offered by the layer thickness chronology associated with this sample. This new sample, stalagmite SU032, grew in close proximity to the previously documented SU967. Radiometric dating (14C) of this 


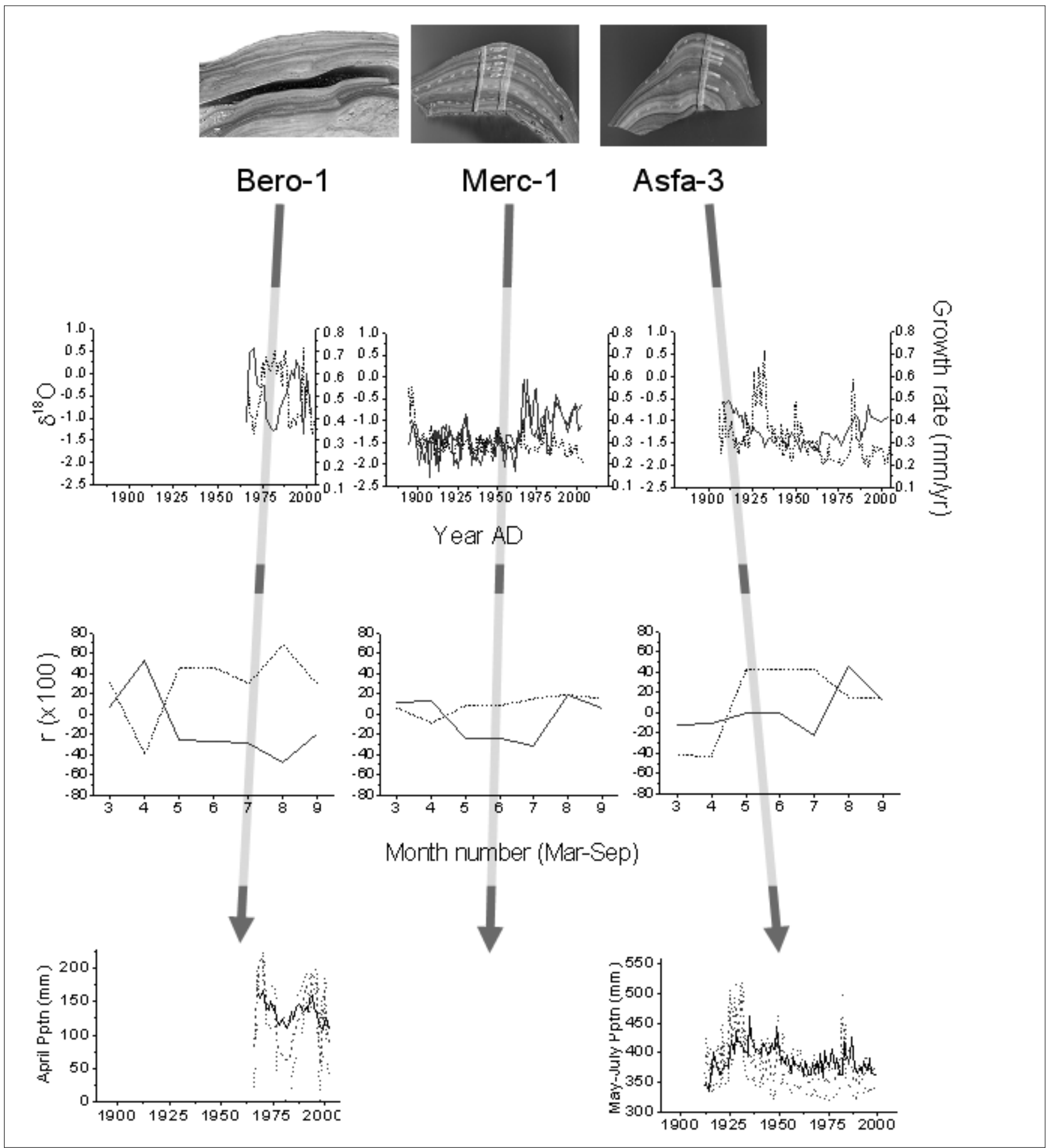

Fig. 9. From top: (a) Top $\sim 100 \mathrm{yr}$ sections of stalagmites Bero-1, Asfa-3, and Merc-1. Merc-1 and Asfa-3 show locations of $\delta^{18} \mathrm{O}$ and 'bomb' ${ }^{14} \mathrm{C}$ analyses; with replicated $\boldsymbol{\delta}^{18} \mathrm{O}$ traverses on Merc-1. (b) Growth rate (black, dashed line) and $\boldsymbol{\delta}^{18} \mathrm{O}$ (blue, solid line) proxies for the three stalagmites. Note the replicated $\boldsymbol{\delta}^{18} \mathrm{O}$ for Merc-1. (c) Correlations between stalagmite proxies and instrumental rainfall. Correlations shown as correlation coefficients, $r, x 100$. Blue, solid lines are for $\boldsymbol{\delta}^{18} \mathrm{O}$ and black dashed lines are for growth rate. (d) April rainfall reconstructed from Bero-1 $\boldsymbol{\delta}^{18} \mathrm{O}$ and summer (May-July) rainfall reconstructed from Asfa-3 growth rate. Thick black line is instrumental data; dashed blue line is reconstructed rainfall with error ranges shown I average.

speleothem confirms this sample was actively growing when collected and a lamina count from the top shows a 326 year record of annual growth (Fuller, 2006). A local calibration approach was used, whereby each stalagmite is initially used to reconstruct local climate conditions through regressional relationships. In the case of the two Scottish stalagmites the information from both annual layer thickness series was used in combination to reproduce the local climate patterns in order to avoid biasing the reconstruction to the Scottish cave site. These local climate calibrations are subsequently tied to the instrumental record for the Northern Hemisphere and used to reconstruct temperature behaviour across this larger spatial extent (Figure 10b). The reconstruction 

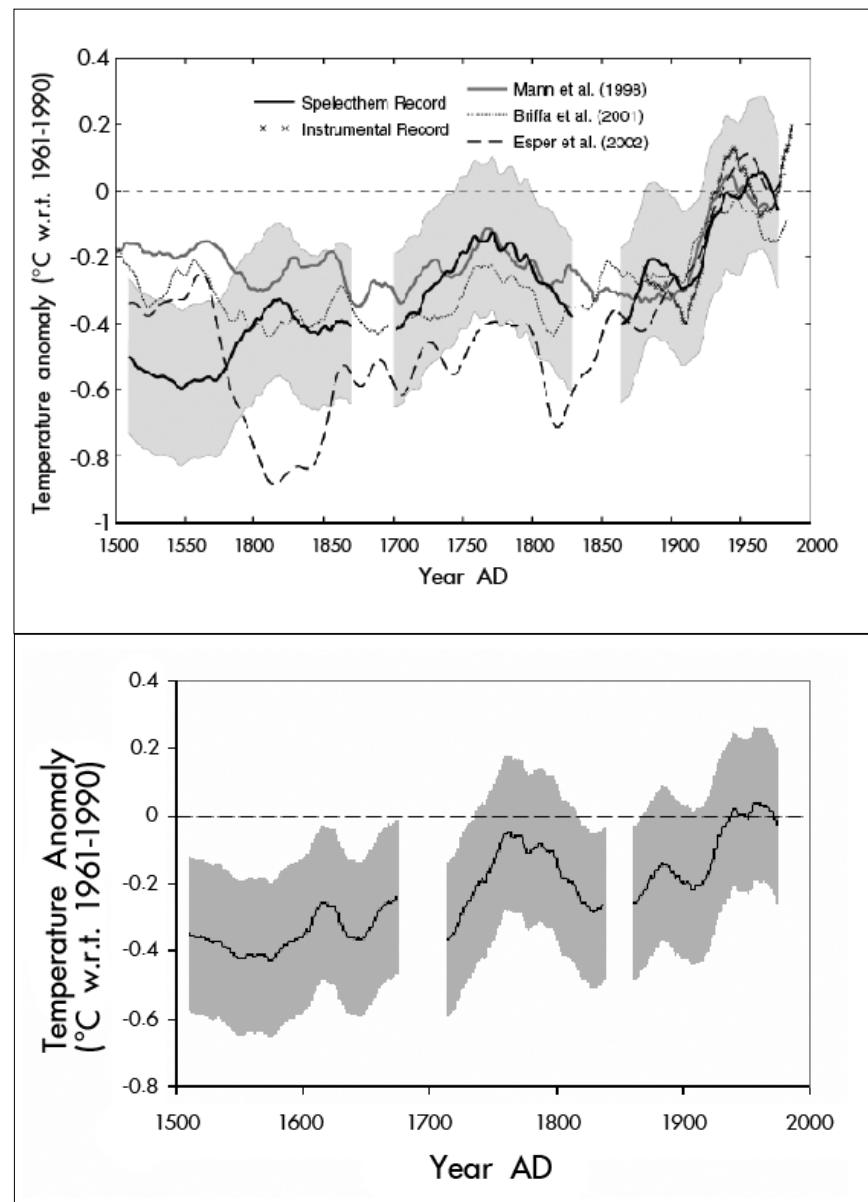

Figure 10. (a) Published Northern Hemisphere mean annual temperature reconstructions smoothed with a 20-year low-pass filter for the past 500 years, together with 3 stalagmite series (from Smith et al., 2006) (b) The new 4-stalagmite reconstruction. Both 3 and 4 stalagmite reconstructions shown with 2 standard error intervals

suggests a temperature increase of $>0.6^{\circ} \mathrm{C}$ over the past 500 years, a significant proportion of which is attributed to the 20th century (66\%). However, the pattern of temperature behaviour inferred from the stalagmites growth is more complex than a simple linear trend, and displays an interesting oscillatory pattern superimposed on the significant longer term trend. The inclusion of the new stalagmite in the temperature reconstruction is found to slightly improve the skill of the hind cast $(\mathrm{RE}=0.344)$, but the overall pattern of behaviour closely matches that of the earlier calibration (Smith et al.2006). The limited alteration of the reconstruction is most likely due to the inclusion of two stalagmites from the same cave, which while enabling valuable site replication does not provide an opportunity to increase the number of spatial degrees of freedom required to capture hemispheric-scale variation. This aspect of largescale stalagmite-climatology holds much promise but is only achievable through the collection and calibration of greater numbers of laminated speleothems from climatologically diverse locations.

\section{CONCLUSIONS}

That annual laminae can be present in speleothems has only recently been accepted both within and outside the science community. Here we suggest that annually laminated stalagmites should be expected in caves where there is strong seasonality in the overlying climate. Annual laminae can be used more frequently and effectively in stalagmite paleoclimate reconstructions than is presently the case, both as a chronology for other proxies or as a lamina width climate proxy. Key issues for future research are:

1) The generation of further long lamina width chronologies over time periods of palaeoclimateimportance e.g. the last 1000 years. With additional samples, it should be possible to develop cross-dating methods if it is possible to demonstrate that the thickness of the growth layers of different stalagmites from the same cave, or from stalagmites from different caves, show the same growth rate trends. Given that different stalagmites within one cave can show a different climate response due to differences in their hydrological connection to the surface, a beneficial concept is to consider 'species' of stalagmite that potentially have similar hydrological connections (e.g. soda-straw fed candlestick stalagmites may be more likely to have more storage (low frequency) signal than curtain fed, broader stalagmites). Smith et al. (2006) demonstrate that low frequency trends in growth rate between caves can correlate with large scale (northern hemisphere temperature) climate, demonstrating the potential for lamina width based climate reconstructions.

2) Automation of lamina measurement. An attempt to standardise the method of deriving a chronology from annual laminae was recently outlined by Tan et al. (2006). However, the process remains somewhat laborious. The automation of the laminae counting process has long been a goal of speleothem research due to the potential savings in time and the reduction in subjectivity that such a tool would offer. Meyer et al. (2006) perhaps provide the first formal software tool that addresses this need, and while their method does require some manual interference it performs well, with reported accuracies of $>90 \%$ and substantial savings of time compared to manual counting. Furthermore, the emerging numbers of trace element laminae series can potentially be counted using a similar algorithm providing a means of intra-stalagmite dating replication, which is a notably absent feature from a large amount of current speleothem climatology.

3) Improved understanding of the relative importance of dripwater chemistry and cave climatology on the formation of visible laminae.

4) The need to develop 'rules' or reporting conventions. E.g (a) reporting the number of transects counted for each given time period and the standard deviation of those measurements, (b) reporting the reproducibility of the replicated annual lamina identification and measurement between different researchers, (c) report calibration statistics with local climate parameters, (d) fully reporting U/Th statistics used forverifying hypothesized annuallaminations, (e) providing a full description of cave and subsurface hydrology, (f) reporting and interpreting the processes explaining any correlation (or lack of it) between lamina widths of overlapping speleothems, (g) fully describing and providing the rational for any normalization / detrending procedures. Similar reporting rules in dendrochronology serves that community well, allows the quality of any chronology to be evaluated by others, and would provide the same opportunity for stalagmite palaeoclimatology. 


\section{ACKNOWLEDGMENTS}

The authors would like to acknowledge the financial support of a Leverhulme Trust International Network, the NERC RAPID program and the University of Birmingham. We also thank Ming Tan for his comments on drafts of this paper.

\section{REFERENCES}

Allison V. C., 1926 - The antiquity of the deposits in Jacob's Cavern. Anthropological Papers of The American Museum of Natural History, 19: 297-335.

Asmerom Y. \& Polyak V.J., 2004 - A test of annual resolution in stalagmites using tree rings. Quaternary Research, 61: 119-121

Baker A., 2001 - Fluorescence excitation-emission matrix characterisation of some sewage impacted rivers. Environmental Science and Technology, 35: 948-953

Baker A. \& Smart P.L., 1995 - Recent flowstone growth rates: field measurements in comparison to theoretical predictions. Chemical Geology, 122: 121-128

Baker A. \& Spencer R.G.M., 2004 - Characterization of dissolved organic matter from source to sea using fluorescence and absorbance spectroscopy. Science of the Total Environment, 333: 217-232.

Baker A., Smart P.L., Edwards R.L. \& Richards D.A., 1993 - Annual growth banding in a cave stalagmite. Nature, 364: 518-520

Baker A., Genty D., Dreybrodt W., Grapes J. \& Mockler N.J., 1998 - Testing theoretically predicted stalagmite growth rate with Recent annually laminated stalagmites: implications for past stalagmite deposition. Geochimica et Cosmochimica Acta, 62: 393-404.

Baker A., Proctor C.J., \& Barnes W.L., 1999a Variations in stalagmite luminescence laminae structure at Poole's Cavern, England, AD1910 to AD 1996: calibration of a palaeoprecipitation proxy. The Holocene, 9: 683-688

Baker A., Mockler N.J., \& Barnes W.L., 1999 Fluorescence intensity variations of speleothemforming groundwaters: Implications for paleoclimate reconstruction. Water Resources Research, 35: 407413

Baker A., Proctor C.J. \& Barnes W.L., 2002 - Stalagmite lamina doublets: a 1,000 year record of extreme winters in $N W$ Scotland. International Journal of Climatology, 22: 1339-1345.

Baker A., Asrat A., Fairchild I.J., Leng M.J., Wynn P.M., Bryant C., Genty D. \& Umer M., 2007 Analysis of the climate signal contained within $\delta^{18} \mathrm{O}$ and growth rate parameters in two Ethiopian stalagmites. Geochimica et Cosmochimica Acta, 71: 2975-2988.

Baldini J.U.L., McDermott F. \& Fairchild I.J. 2002 Structure of the '8,200' year' cold event revealed by a high-resolution speleothem record. Science, 296: 2203-2206.

Ban F., Pan G., \& Wang X., 2005 - Timing and possible mechanism of organic substance formation in stalagmite laminae from Beijing Shihua Cave. Quaternary Sciences, 25: 265-268 (in Chinese)
Ban F., Pan G., Zhu J., Cai B \& Tan M. 2008 - Temporal and spatial variations in the discharge and dissolved organic carbon of drip waters in Beijing Shihua Cave, China. Hydrological Processes, in press DOI: 10.1002/ hyp. 6979

Baskaran M. \& Iliffe T.M., 1993 - Age-determination of recent cave deposits using excess $\mathrm{Pb}-210$ - a new technique. Geophysical Research Letters, 20: 603-606

Bertaux J., Sondag F., Santos R., Soubies F., Causse C., Plagnes V., Le Cornec F. \& Seidel A, 2002 - Paleoclimatic record of speleothems in a tropical region: study of laminated sequences from a Holocene stalagmite in Central-West Brazil. Quaternary International, 89: 3-16

Borsato A., Frisia S., Fairchild I.J., Somogyi A. \& Susini J., 2007 - Trace element distribution in annual stalagmite laminae mapped by micrometer-resolution $X$-ray fluorescence: Implications for incorporation of environmentally significant species. Geochimica et Cosmochimica Acta, 71: 1494-1512.

Boyer E.W., Hornberger G.M., Bencala K.E. \& McKnight D.M., 1997 - Response characteristics of DOC flushing in an alpine catchment. Hydrological Processes, 11: $1635-1647$.

Broecker W. S., Olson E.A. \& Orr P.C., 1960 - Radiocarbon measurement and annual rings in cave formations. Nature, 185: 93-94.

Brook G. A, Rafter M.A., Railsback L.B., Sheen S.W. \& Lundberg J., 1999 - A high-resolution proxy record of rainfall and ENSO since $A D 1550$ from layering in stalagmites from Anjohibe Cave, Madagascar. The Holocene, 9: 695-705.

Burns S. J., Fleitmann D., Mudelsee M., Neff U., Mangini A. \& Matter A., 2002 - A 780-year annuallyresolved record of Indian Ocean monsoon variation in a speleothem from south Oman. Journal of Geophysical Research, 107: D20, art. no. 4434

Charman D.J., Caseldine C.J., Baker A., Gearey B. \& Hatton J., 2001 - Palaeohydrological records from peat profiles and speleothems in Sutherland, NW Scotland. Quaternary Research, 55: 223-234.

Coble P.G., 1996 - Characterization of marine and terrestrial DOM in seawater using excitation emission matrix spectroscopy. Marine Chemistry, 51: 325-346

Condomines M. \& Rihs S., 2006 - First Ra-226-Pb-210 dating of a young speleothem. Earth and Planetary Science Letters, 250: 4-10

Del Vecchio R. \& Blough N.V., 2002 - Photobleaching of chromophoric dissolved organic matter in natural waters: kinetics and modelling. Marine Chemistry, 78: 231-253

Denniston R.F., Gonzalez L.A., Asmerom Y, Sharma R.H. \& Reagan M.K., 2000 - Speleothem evidence for changes in Indian summer monsoon precipitation over the last similar to 2300 years. Quaternary Research, 53: 196-202.

Desmarchelier J.M., Hellstrom J.C., \& McCulloch M.T., 2006 - Rapid trace element analysis of speleothems by ELA-ICP-MS. Chemical Geology, 231: 102-117

Dreybrodt W., 1980 - Deposition of calcite from thin films of natural calcareaous solutions and the growth of speleothems. Chemical Geology, 29: 89-105. 
Dreybrodt W., 1981 - The kinetics of calcite deposition from thin films of natural calcareous solutions and the growth of speleothems: revisited. Chemical Geology, 32: 237245

Dreybrodt W., 1988 - Processes in Karst Systems. SpringerVerlag, 288 p., Berlin.

Fairchild I.J., Baker A., Borsato A., Frisia S., Hinton R.W., McDermott F. \& Tooth A.F. 2001 - Annual to sub-annual resolution of multiple trace-element trends in speleothems. Journal of the Geological Society, 158: 831-841

Fairchild I.J., Frisia S., Borsato A. \& Tooth A.F., 2007 - Speleothems. In: Geochemical Sediments and Landscapes. RGS-IBG book series. Blackwells, Oxford, UK. ISBN 1405121595

Frisia S., Borsato A., Fairchild I.J. \& McDermott F., 2000 - Calcite fabrics, growth mechanisms, and environments of formation in speleothems from the Italian Alps and Southwestern Ireland. Journal of Sedimentary Research, 70: 1183-1186.

Frisia S., Borsato A., Fairchild I.J., McDermott F. \& Selmo E.M., 2002 - Aragonite-calcite relationships in speleothems (Grotte de Clamouse, France): Environment, fabrics, and carbonate geochemistry. Journal of Sedimentary Research, 72: 687-699

Frisia S., Borsato A., Preto N. \& McDermott F., 2003 Late Holocene annual growth in three Alpine stalagmites records the influence of solar activity and the North Atlantic Oscillation on winter climate. Earth and Planetary Science Letters, 216: 411-424

Fuller L., 2006 - High resolution multiproxy geochemical Holocene climate records from 1000-year old Scottish stalagmites. Unpublished $\mathrm{PhD}$ thesis, University of Birmingham.

Gao Q., Tao Z., Shen C., Sun Y., Yi W. \& Xing C., 2002 - Riverine organic carbon in the Xijiang River (South China): seasonal variation in content and flux budget. Environmental Geology, 41: 826-832.

Genty D., 1992 - Les spéléothèmes du tunnel de Godarville (Belgique) - un exemple exceptionnel de concrétionnement moderne - intérêt pour l'étude de la cinétique de la précipitation de la calcite et de sa relation avec les variations d'environnement. Speleochronos, 4 : 3-29

Genty D., 1993 - Mise en évidence d'alternances saisonnières dans la structure interne des stalagmites. Intérêt pour la reconstitution des paléoenvironnements continentaux, Comptes Rendus Académie des Sciences Paris, Série II, 317: 1229-1236.

Genty D. \& Quinif Y., 1996 - Annually laminated sequences in the internal structure of some Belgian stalagmites importance for paleoclimatology. Journal of Sedimentary Research, 66: 275-288

Genty D. \& Massault M., 1997 - Bomb ${ }^{14} \mathrm{C}$ recorded in laminated speleothems - part 1: dead carbon proportion calculation, Radiocarbon, 39: 33-48

Genty D. \& Deflandre G., 1998 - Drip flow variations under a stalactite of the Père Noël cave (Belgium): evidence of seasonal variations and air pressure constraints. Journal of Hydrology, 211: 208-232.

Genty D., QuinifY. \& Deflandre G., 1995 - Microséquences de lamines annuelles dans deux stalagmites du massif de Han-sur-Lesse (Belgique), Spéléochronos, 6 : 9-22.
Genty D., Baker A. \& Barnes W.L., 1997a - Comparison of annual luminescent and visible laminae in stalagmites. Comptes Rendus Académie des Sciences Paris, Serie II, 325 : 193-200

Genty D., Deflandre G., Quinif Y. \& Verheyden S., 1997b - Les lamines de croissance des spéléothèmes: origine et intérêt paléoclimatique, Bulletin de la Société belge de Géologie, 106 : 63-77

Genty D., Vokal B., Obelic B. \& Massault M., 1998 - Bomb ${ }^{14} \mathrm{C}$ Time History Recorded in two modern stalagmites Importance for soil organic matter dynamics and bomb ${ }^{14} \mathrm{C}$ distribution over continents. Earth and Planetary Science Letters, 160: 795-809

Genty D., Baker A. \& Vokal B., 2001 - Inter and intra annual growth rates of European stalagmites. Chemical Geology, 176: 193-214.

Huang Y., Fairchild I.J., Borsato A., Frisia S., Cassidy N.J., McDermott F. \& Hawkesworth C.J. 2001 - Seasonal variations in Sr, Mg and P in modern speleothems (Grotta di Ernesto, Italy). Chemical Geology, 175: 429-448

Hudson N.J., Baker A. \& Reynolds D. 2007 - Fluorescence analysis of dissolved organic matter in natural, waste and polluted waters - a review. Rivers Research, 23: 631-649.

Jex C., Claridge E., Baker A. \& Smith C.L., 2007 Hyperspectral imaging of speleothems. Quaternary International, 187: 5-14

Kendall A.C. \& Broughton P.L., 1978 - Origin of fabrics in speleothems composed of columnar calcite crystals. Journal of Sedimentary Petrology, 48: 519-538.

Kong X.G., Wang Y.J., Wu J.Y. \& Cheng H, 2003 - A continuous 3000-year precipitation record of ENSO variability during LGM from a stalagmite in Nanjing. Chinese Science Bulletin, 48: 480-484

Kuczumow A., Genty D., Chevallier P., Nowak J. \& Ro C.-U. 2003 - Annual resolution analysis of a SW-France stalagmite by X-ray synchrotron microprobe analysis. Spectrochimica Acta Part B - Atomic Spectroscopy, 58: 851-865

Lauritzen S.E., Ford D.C. \& Schwarz H.P., 1986 - Humic substances in a speleothem matrix. Proceedings of the 9th International Congress of Speleology, 77-79.

Linge H., Lauritzen S.E., Baker A., \& Proctor C.J., 2001 - Luminescent growth banding and stable isotope stratigraphy in a stalagmite from Northern Norway: preliminary results for the period AD1734 to $955 B C$. Proceedings of the 13th International Congress of Speleology.

McMillan E.A., Fairchild I.J., Frisia S., Borsato A. \& McDermott F. 2005 - Annual trace element cycles in calcite-aragonite speleothems: evidence of drought in the western Mediterranean 1200-1100 yr BP. Journal of Quaternary Science, 20: 423-433

Meyer M.C., Faber R. \& Spötl C., 2006 - The WinGeol Lamination Tool: new software for rapid, semiautomated analysis of laminated climate archives. The Holocene, 16: 753-761.

Moberg A., Sonechkin D. M., Holmgren K., Datsenko N.M., Kerlen W. \& Lauritzen S.E., 2005 - Highly variable Northern Hemisphere temperatures reconstructed from low- and high-resolution proxy data, Nature, 433: 613-617. 
Mounier S., Braucher R. \& Benaim J.Y., 1999 Differentiation of organic matter's properties of the Rio Negro basin by crossflow ultra-filtration and UVspectrofluorescence. Water Research, 33: 2363-2373

Onac B. P. 1997 - Crystallography of speleothems. In: Hill, C.A., Forti, P., (Eds.). Cave minerals of the world, 2nd ed., NSS, Huntsville, Alabama, 230-236.

Orr P.C., 1952 - Excavations in Moaning Cave. Santa Barbara Museum of Natural History Bulletin, 1: 19pp.

Paulsen D.E., Li H.C. \& Ku T.L., 2003 - Climate variability in central China over the last 1270 years revealed by high-resolution stalagmite records. Quaternary Science Reviews, 22: 691-701

Perrette Y., Delannoy J.J., Desmet M., Lignier V. \& Destombes J.L., 2005 Speleothem organic matter content imaging. The use of a Fluorescence Index to characterise the maximum emission wavelength. Chemical Geology, 214: 193-208

Polyak V.J. \& Asmerom Y., 2001 - Late Holocene climate and cultural changes in the Southwestern United States, Science, 294: 148-151

Proctor C. J., Baker A., Barnes W. L. \& Gilmour M. A., 2000 - A thousand year speleothem proxy record of North Atlantic climate from Scotland. Climate Dynamics, 16: 815-820

Proctor C.J., Baker A. \& Barnes W. L., 2002 - A three thousand year record of $N$ Atlantic climate. Climate Dynamics, 19: 449-454

Qin X., Tan M., Liu T., Wang X.F., Li T.Y. \& Lu J.P., 1999 - Spectral analysis of a 1000-year stalagmite laminathickness record from Shihua Cavern, Beijing, China, and its climatic significance. The Holocene, 9: 689-694

Railsback L. B., Brook G. A., Chen J., Kalin R. \& Fleisher C. J., 1994 - Environmental control on the petrology of a late Holocene speleothem from Botswana with annual layer of aragonite and calcite. Journal of Sedimentary Research, 64: 147-155

Rasbury M. \& Aharon P., 2006 - ENSO-controlled rainfall variability records archived in tropical stalagmites from the mid-ocean island of Niue, South Pacific. Geochemistry, Geophysics, Geosystems, 7: Art. No. Q07010

Ribes A.C., Lundberg J., Waldron D.J., Vesely M., Damaskinos S., Guthrie S.I. \& Dixon A.E., 2000 Photoluminescence imaging of speleothem microbanding with a high-resolution confocalscanning lasermacroscope. Quaternary International 68: 253-259

Roberts M.S., Smart P.L. \& Baker A., 1998 - Annual trace element variations in a Holocene Speleothem. Earth and Planetary Science Letters, 154: 237-246

Shopov Y.Y., Dermendjiev V. \& Buykliev G., 1989 Investigation on the variations of the climate and solar activity by a new method - llmza of cave flowstone from Bulgaria. Proceedings of the 10th International Congress of Speleology, 95-97.

Shopov Y.Y., Ford D.C. \& Schwarz H.P., 1994 - Luminescent microbanding in speleothems - high-resolution chronology and paleoclimate. Geology, 22: 407-410

Smith C.L., Baker A., Fairchild I.J. \& Frisia S., 2006 - Reconstructing Regional Climates from Multiple Stalagmite Records. International Journal of Climatology, 26: 1417-1424.
Soubies F., Seidel A., Mangin A., Genty D., Ronchail J., Plagnes V., Hirooka S. \& Santos R., 2005 - A fifty-year climatic signal in three Holocene stalagmite records from Mato Grosso, Brazil. Quaternary Science Reviews, 135: 115-129.

Spötl C., Fairchild I.J. \& Tooth A.F., 2005 - Cave air control on dripwater geochemistry, Obir Caves (Austria): implications for speleothem deposition in dynamically ventilated caves. Geochimica et Cosmochimica Acta, 69: 2451-2468.

Tan M., Liu T.S., Hou J.Z., Qin X.G., Zhang H.C. \& Li. T.Y., 2003 - Cyclic rapid warming on centennnial-scale revealed by a 2650-year stalagmite record of warm season temperature. Geophysical Research Letters, 30: 191-194

Tan M., Hou J., \& Cheng H., 2002 - Methodology of quantitatively reconstructing paleoclimate from laminated stalagmites. Quaternary Sciences, 22: 209219 (in Chinese)

Tan M., Liu T., Qin X. \& Zhang D., 1997 - Microbanding of stalagmite and its significance. PAGES News, 5: 6-7

Tan M., Qin X.G., Shen L.M., Wang X.F., Wang Y.J., Li T.Y., Song L.H., Wang L.H. \& Liu D.S., 1999 - Bioptical microcycles of laminated speleothems from China and their chronological significance. Chinese Science Bulletin, 44: 1604-1607

Tan M., Baker A., Genty D., Smith C., Esper J. \& Cai B., 2006 - Applications of stalagmite laminae to paleoclimate reconstructions: comparison with dendrochronology/climatology. Quaternary Science Reviews, 25: 2103-2117

Treble P., Shelley J.M.G. \& Chappell J., 2003 Comparison of high resolution sub-annual records of trace elements in a modern (1911-1992) speleothem with instrumental climate data from southwest Australia. Earth and Planetary Science Letters, 216: 141-153

Treble P.C., Chappell J. \& Shelley J.M.G., 2005 - Complex speleothem growth processes revealed by trace element mapping and scanning electron microscopy of annual layers. Geochimica et Cosmochimica Acta, 69: 48554863

White W.B. \& Brennan E.S., 1989 - Luminescence of speleothems due to fulvic acid and other activators. Proceedings of the $10^{\text {th }}$ International Congress of Speleology, 212-214.

Worrall F., Harriman R., Evans C.D., Watts C.D., Adamson J., Neal C., Tipping E., Burt T., Grieve I., Monteith D., Naden P.S., Nisbet T., Reynolds B. \& Stevens P., 2005 - Trends in dissolved organic carbon in UK rivers and lakes. Biogeochemistry, 70: 369-402

Wurth G., Götte T., Niggemann S. \& Richter D.K. 2003 - Annual rhythmics in a Holocene stalagmite from Zoolithen Cave, Germany - Visual lamination and high-resolution PIXE-based Mg analyses. Proceedings of the conference 'Climate change - The Karst Record III', 180-181, Montpellier

Yadava M.G., Ramesh R. \& Pant G.B., 2004 - Past monsoon rainfall variations in peninsular India recorded in a 331-year-old speleothems. The Holocene, 14: 517-524. 